Agronomy Journal of Nepal (Agron JN) Vol. 3. 2013

\title{
Outreach Research: A liaison between research and extension
}

\author{
MN Paudel \\ Outreach Research Division, Khumaltar, NARC
}

\begin{abstract}
How outreach research has been passed through due course of time in Nepal is put forth. A model of linkages of outreach research in relation to technology dissemination as a liaison between research and extension in the Nepalese context has been shown in a broad perspective. Similarly, how technology is delivered from research station to farmers' fled in a participatory approach involving public-private-partnership through research-extension interphase is mentioned. Also, the relation of outreach research with extension from district to central level is illustrated. There is clear message that why technology generation do not tailor with the demand of client and every concerned institute should dare to accept pros and cons of agro-technology cycle to enhance agriculture and productivity to meet the food security of Nepalese people. This paper explains the limitation and opportunities of agriculture research and development which are not getting priority in a way these should be considered to take pace with present day demand.
\end{abstract}

Key words : outreach research, interphase, research-extension linkage, ATWG, RATWGs, agrotechnology transfer model

\section{Historical perspective}

During 1960's Parwanipur Agriculture Farm initiated distribution of minikits on crops such as rice, maize, wheat, potato, and grain legumes which was the first formal start of outreach research (OR) in Nepal (ORD, 2007). Outreach as the extending of service beyond usual limits, and requiring the better by trickery. This holds true in our real case that why many of the promising agricultural technologies developed in research stations fail to reach in farmers' field. In other ways there lacks a vision, which takes technologies to the end users without seriously understanding the meaning of outreach research. To understand the meaning of OR, the National Agriculture Research and Service Center (NARSC, 1987), the predecessor of NARC, has given a pragmatic definition of outreach that "referred outreach programs as a combination of adaptive research and service activities conducted by researchers that assist extension personnel to disseminate technology. The adaptive research component is conducted by research personnel in collaboration with extension personnel in farmers' field to verify technology, and adapt it with necessary relevant research agencies in order to make the technology more useful to farmers". Currently the definition and boundary of outreach research has broadened with the recent development of participatory and pluralistic model of technology development and emergence of non-traditional actors (I/NGOs, CBOs and private sector) in agricultural research and development (Gauchan et al., 2000). Therefore, OR is currently seen as a method of participatory technology development and dissemination which involves interactive participation and partnerships of farming communities and diverse actors from both public, private and civil society sectors in bringing together their knowledge and practices and research capacity (ORD, 2000). 


\section{Methodology}

This paper is amalgamation of the data related to outreach research coupled with published data and information pertaining to agriculture research and development. Data are used from published sources of Nepal Agriculture Research council (NARC), Ministry of Agriculture and development (R\&D) and other relevant print and electronic sources. Often time, personal communications with concerned experts and outcome of discussion in technical forums have also been incorporated in the paper. Besides, author's professional experience in agriculture $\mathrm{R} \& \mathrm{D}$ are also internalized herein as well.

\section{Results and discussions}

\section{Linkage of agricultural research and development}

It is logical that that agrotechnology should passes through different tyres from district to region to national level (Fig. 2) before it is actually taken to the end users. Under network of extension in 75 districts there is a meeting of the District Agriculture Technical Working Groups (DATWG) jointly organized by District Agriculture Development Offices (DADSOs) and District Livestock Service (DLS) offices once in a year. The DATWG is conducted principally in one of the meetings of District Technical Coordination Meetings (DTCM) in district in which DADOs and DLS of every district are the member secretary of DTCM and of the three meetings one meeting of DTCM is fully devoted for DATWG to discuss issues of agriculture in the districts. Grassroots level researchable problems and issues are taken to regional level giving location specific thrusts so that Regional/ Agricultural Research stations (R/ARSs) and commodity programs could address these concerns. In practice, DATWG meeting in every district has not been taking place regularly due to lack of effective M\&E from the higher offices including regional and ministerial level by the Department of Agriculture (DoA) and the Ministry of Agriculture Development (MoAD).

The second tyre meeting starts in regional level in the form of Regional Agricultural Technical Working Groups (RATWGs) workshop which should be done by DLS, DoA and NARC in every region in first second and third trimesters of each fiscal year (Fig. 2). From these RATWGs, regional level issues are addressed by the concerned R/ARS and commodity program if there are solutions to the issues raised by service providers. If new issues are raised and there is a need to generate technology on issue raised, scientists design experiment to address the issues which follow the cycle as indicated in the Fig 1 unless answer is found out.

Finally, there is the National Agricultural Technical Working Group (NATWG) workshop is to be organized by NARC once in a year in the central level consisting of higher authorities of the MoAD, NARC, DoA, DLS and all concerned stakeholders. Thus, NATWG addresses issues raised in DATWGs and RATWGs to make technology generation, verification and delivery in a smooth way under PPP model. There is always a good question to ask. are all of these theoretical concepts are followed appropriately? To answer this, there should be the combination of all five senses viz; eye, ear, nose, skin, tongue and sense of research, extension, and clienteles under MoAD. Every concerned institute should dare to accept pros and cons of agro-technology cycle to enhance agriculture and productivity to meet the food security of Nepalese people. 


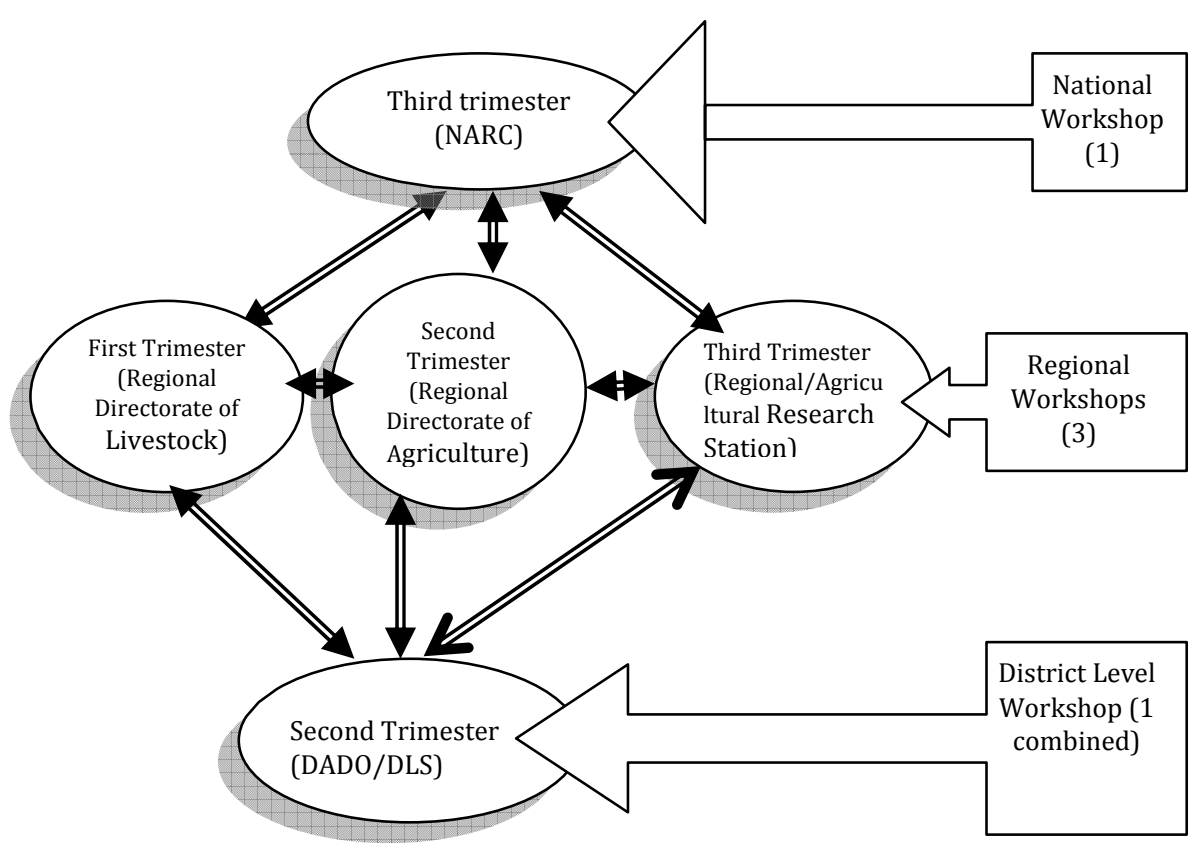

Fig. 1. Three tires Cycle model of ATWG (Implementation guidelines for ATWG, 2065)

\section{Liaison between research and extension}

A model of agro-technology development and dissemination has been outlined (Paudel and Thakur, 2008) in Nepal (Fig, 2). This model depicts how agro-technology is generated, verified and disseminated to the end users/clienteles. The model is based on participatory concept involving public-private-partnership where international, national, regional, and local stakeholders are linked to agriculture research and development $(\mathrm{R} \& \mathrm{D})$. The limit of research is up to OR site where extension agencies are supposed to take fine tuned technologies for wider dissemination. Nepal Agricultural Research Council (NARC) is responsible for technology development while Department of Agriculture (DoA), Department of Livestock Services (DLS) and Community Based Organizations (CBOs) are the partners of technology dissemination. International/National Government Organizations (I/NGOs) are involved into research and development according to their priority and target set as shown in Fig. 1. OR is the interface between research and extension. It is more like to research when feedbacks received from extension are taken to research stations and remodeled according to the need of clienteles. On the other hand, it is more like to extension when technology generated at research stations are verified in OR site with active involvement of farmers. 


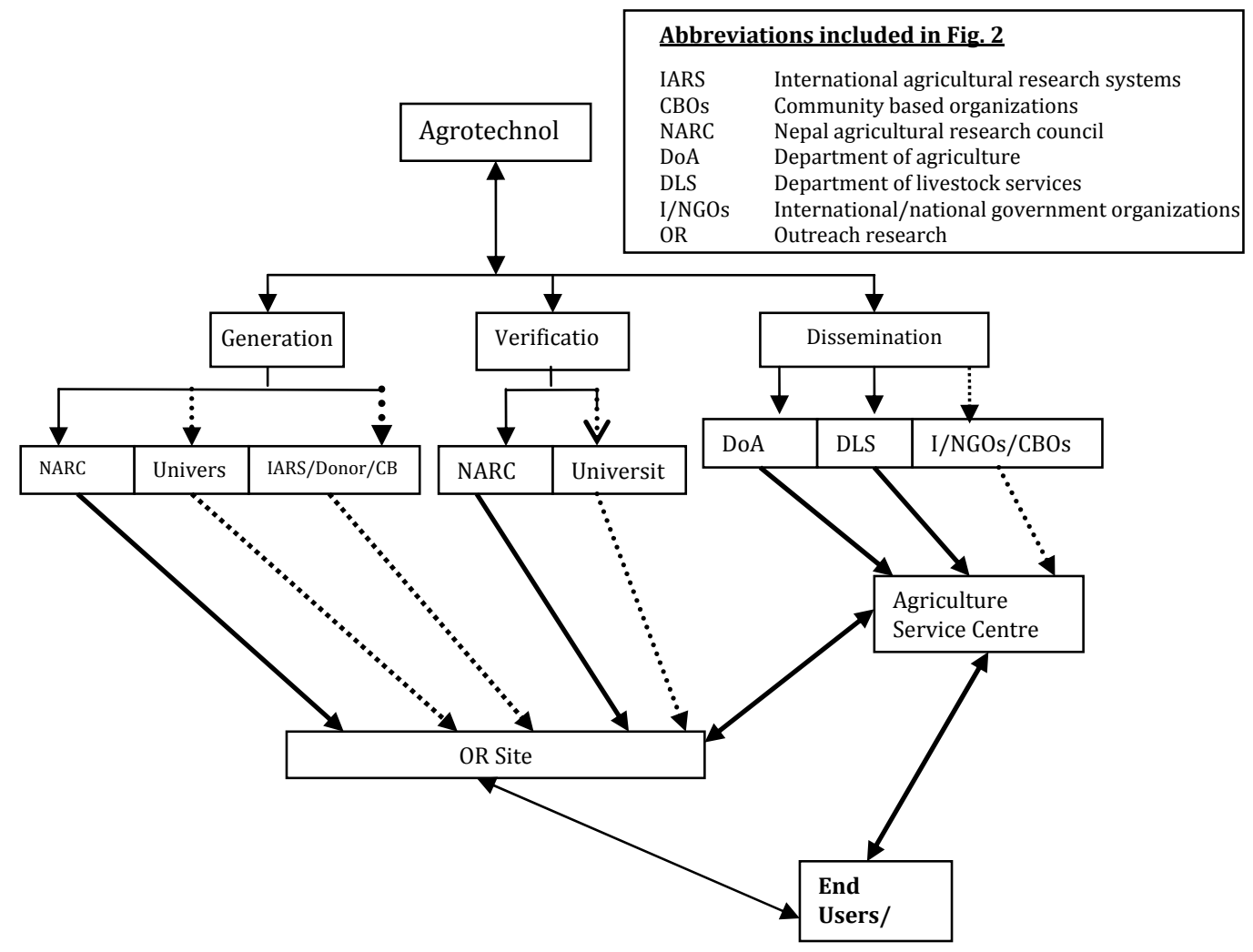

Fig. 2 Agro-technology development and transfer model in Nepal (Paudel and Thakur, 2008)

\section{Challenges}

Agriculture systems in Nepal has been facing many challenges, however the important challenges are given below.

\section{Low and declining investment}

Dahal and Khanal (2010) reported that public expenditure on agriculture has been gradually declined since 1990 when the government started liberal economic policy in the country. They also observed that agriculture remained no longer a priority sector in Nepal as a result the national budget allocation to the Ministry of Agriculture and Cooperatives (MoAC) went down to one of the lowest levels, 2.45 percent in 2006/07 and 2.47 percent in 2007/08. The impact of low priority for agriculture in the country resulted poor service delivery of agricultural extension and severe constraints in research and technology generation. They found that agriculture research suffered more than extension as it is included under second priority for which national outlay in 2003/04 the NARC's budget allocation was 0.30 percent which is grossly insufficient to produce any significant research and development outputs. 
There is limited and declining public funding for agricultural research despite its potential technological contribution to agricultural development and economic growth in Nepal. Public investment is less than $0.20 \%$ of AGDP which is below the international norm of providing about $2 \%$ of AGDP for agricultural research. The trend of the operational budget of NARC clearly shows poor investment in research in recent years. In the contemporary world, agriculture research is funded by the government of every county for it is directly linked to the livelihood of people. In contrary to this, the government of Nepal has still not fully internalized that research is its responsibility and there should not be dearth of logistic and human resource to address the issues of food security and livelihood of Nepalese people through agriculture development.

In 2010, Pascal Lamy, Director General, World Trade Organization, admitted that agriculture subsidy would remain at levels up to four times higher than in industry as a contribution to the problem of food security (THT, February 25, 2010). Therefore, it explains that agriculture should get more investment at least four time surge of budget in Nepal to get priority to address food shortage. However, agriculture in Nepal since seventh five year plan has not received priority from the government as a consequence present food shortage has been looming large. In 2010, Nepal faces food deficit of 0.316 million metric tons due to 0.5 million metric tons decrease of rice production compared to the last year (Republica Daily May 30, 2010). It is worth to increase local productivity of crops instead of air lifting rice to the remote areas where there is food shortage. Therefore, it is anticipated that government of Nepal should give due priority to address local food shortage by providing incentives to boosting local food productivity. This can be done by investing more on local food resources instead of providing transport subsidies to air lift food aids from outside

\section{Yield gaps and food shortage}

Farm level productivity of most of food crops and livestock is low and fall below $50 \%$ of the attainable potential than that of experimental plots. For example in 2012, the average attainable yield of major staple crops is 4-6 t/ha and the national average is around 2-3.3 $\mathrm{t} / \mathrm{ha}$ whereas yield gap is more than their national average (Fig.3). This could be done if strong commitment is placed for agriculture by the government because research has proved that attainable yield of major food crops could be doubled than that of present average yield.

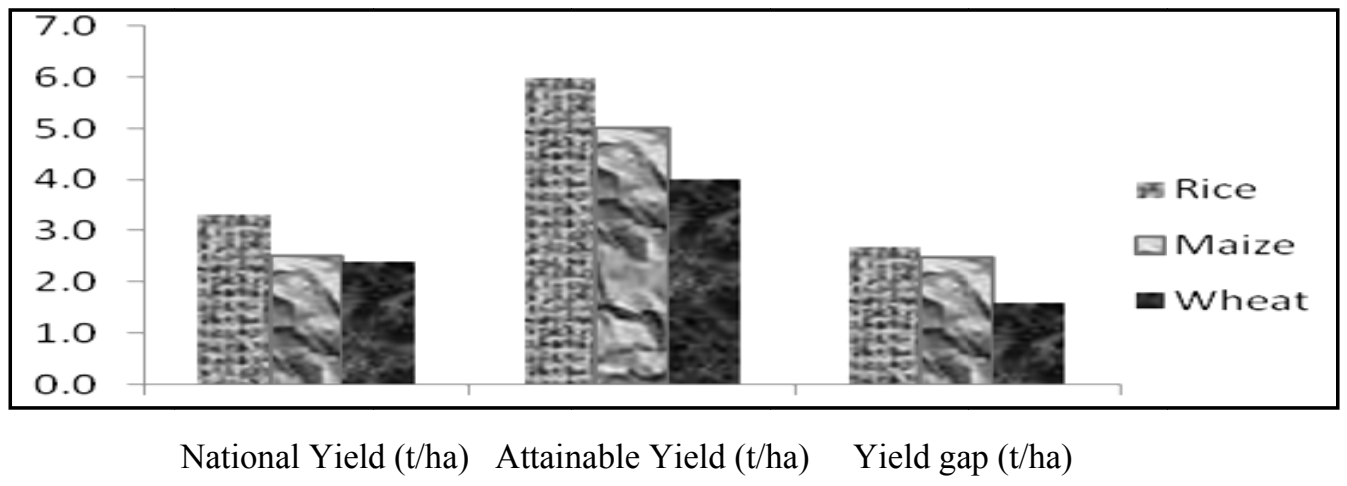

Fig. 3 Yield level comparison of major cereals 2012 


\section{Climate change}

Impact of climate change in Nepal could be observed in varying level of climates that are prevalent in diversified topography and vegetation present in Nepal. Broadly there are impacts of climate changes in Nepal; Terai (almost tropical region), mid hills and valley (subtropical region), and mountains and Himalaya (temperate and tundra regions). It is reported (Ujaylo FM, 27 June 2009) that there is no snow in the Api Himal of mid western region at 15000 feet and pioneer mountaineer Mr. Apa Sherpa, (2010) observed drastic changes in the climate of the Himalayas regions and speaks "the changes in weather patterns are drastic. It didn't snow at all during December, January and February, when it should snow heavily, and it finally snowed massively in May, when usually it's dry." Apa scaled the Mount Everest 21 times up to 2012 and experienced while climbing the Everest in June 2009 that there was no snow in the Everest trail and he waited snow fall for days at the base camps to scale the Everest for without snow the scaling of the Everest is virtually impossible and there is no chance of kissing the Everest (Sagarmatha,) peak, the roof of the world. Apa scaled the Everest $20^{\text {th }}$ time on 23 May 2010 and noticed that there was stream flowing on top of the Everest by melting ice. A country like Nepal could not explain more than this as the impact of climate changes in the Himalayan region- the experience of Apa! If the Himalayas peaks are devoid of snow what would be the fate of rivers flowing from those mighty water towers, the Himalayas. If such issues of climate change are not addressed timely the adverse impact of climate change in Nepal could affect remote areas making food shortage more vulnerable in coming days as well and other development aspects such as health, education, rural infrastructures etc could be jeopardized adversely.

\section{Opportunities}

There are plenty of opportunities to address the challenges created by food insecurity and climate change with respect to increase agriculture production. Contemporary countries in this part of the world have been able to address such challenges and there are instances of these countries which have put high priority in agriculture and are being able to raise living standard of people without sacrificing their livelihood enhancement. Some of the ways to address vagaries of low production of agriculture have been suggested herewith as followings.

\section{Increase production and local food sufficiency}

Up to mid eighties Nepal was a food exporting country (Table 1) and food deficiencies in these days have been increasing. It is report that there is hunger and malnutrition looming large almost in every year in remote districts of Nepal. In 2009/10 3.9 million populations in the mid and far western region are suffering from food shortage (MoAC 2009). Food shortage can be addressed by making food availability locally. Government is air lifting rice to feed the hungry mouth. This practice has been making people dependent on outside foods. Short term and long term strategies should be adopted to address food shortage. Emphasis should be given to encourage local food crop production and some income generation activities and conservation and management of local food resources should be the agriculture priority and dependency on air lifting rice should be discouraged. Such practice will empower local people and outside dependency on food requirements will be decreased. This will help conserve biodiversity and make people food self sufficiency in the long run. 
Table 1. Edible cereal production requirement and balance (' $000 \mathrm{mt})^{*}$

\begin{tabular}{lllllll}
\hline F/Y & $\mathbf{1 9 6 4 / 6 5}$ & $\mathbf{1 9 8 4} / \mathbf{8 5}$ & $\mathbf{1 9 9 4 / 9 5}$ & $\mathbf{2 0 0 3 / 0 4}$ & $\mathbf{2 0 1 0 / 1 1}$ & $\mathbf{2 0 1 1 / 1 2 * *}$ \\
\hline Production & 2212 & 2595 & 3398 & 4884 & 5513 & 6038 \\
Requirement & 1919 & 2500 & 3883 & 4671 & 5070 & 5151 \\
Balance & 293 & 95 & -485 & 213 & 443 & 886 \\
\hline
\end{tabular}

*MoAD, 2012, **preliminary

Productivity of major staples (rice, maize, and wheat) is almost stagnant (Table2) and it is far below the attainable yield of these crops which has been discussed in the previous section. Targeted yield achievement for these crops should be the R for D priority of the government. Rice is the main food which provides around $45 \%$ of food requirement to the people. Emphasis should be given to increase productivity of these staples in general and rice in particular. Productivity of these crops should be increased many folds $(45-75 \%)$ to meet the food demand of the country which is projected (Table 2).

Table 2. Cereal crops area production and productivity in 2009* against projected productivity as of 2009

\begin{tabular}{lccccc}
\hline Crop & $\begin{array}{l}\text { Area } \\
\text { ('000 } \\
\text { ha) }\end{array}$ & $\begin{array}{l}\text { Production } \\
\text { ('000 } \mathbf{m t})\end{array}$ & $\begin{array}{l}\text { Productivity } \\
\text { (mt/ha) }\end{array}$ & $\begin{array}{l}\text { Projected productivity to meet } \\
\text { food requirement (t/ha) }\end{array}$ & $\begin{array}{l}\text { increase } \\
\text { productivity } \\
\text { over 2009 to } \\
\text { meet food } \\
\text { requirement }\end{array}$ \\
\hline Rice & 1556 & 4524 & 2.9 & $5.013(45 \%$ share in food sufficiency $)$ & 72.9 \\
Maize & 875 & 1931 & 2.206 & $2.674(30 \%$ share in food sufficiency $)$ & 29.7 \\
Wheat & 695 & 1344 & 1.93 & $2.805(25 \%$ share in food sufficiency $)$ & 45.3 \\
Total & 3126 & 7799 & 2.5 & $2.5\left(100 \%{ }^{\text {share in food sufficiency })}\right.$ & 0 \\
\hline
\end{tabular}

*MoAC, 2009

\section{High priority for agriculture}

Nepal's investment on agriculture is poor compared to South Asian countries. An illustration to this effect to attain national and household food security how much investment in agriculture is needed to attain an AGDP in two different scenarios has been illustrated (Table 3). The declining investment in agriculture amounts to utter negligence of and indifference to the needs of the poor, especially the resource-poor farmer (Singh, 2009). He further highlighted that investments in agricultural R\&D have paid off handsomely, with an average internal rate of return of about 40 percent and have been highly pro-poor and investment in agricultural R\&D tripled in China and in India over the past 20 years, it increased only slowly in most other countries. For these countries, sharply increased investment and regional cooperation in R\&D are urgent to bridge productivity, income and development gaps. 
Table 3. Required investment in agricultural $R \& D$ to attain food security and to reduce poverty and hunger in South Asia* (Current price in million US\$)

\begin{tabular}{|c|c|c|c|c|c|}
\hline Country & 2002 & 2010 & 2015 & 2020 & 2025 \\
\hline Scenario 1 & \multicolumn{5}{|c|}{$2.14 \%$ agricultural growth (to attain national food security) } \\
\hline Bangladesh & 101.2 & 143.0 & 177.5 & 220.3 & 273.5 \\
\hline India & 1258.3 & 1778.0 & 2206.9 & 2739.3 & 3400.0 \\
\hline Nepal & 24.1 & 34.2 & 42.4 & 52.6 & 65.2 \\
\hline Pakistan & 158.8 & 224.4 & 278.5 & 345.7 & 429.2 \\
\hline Sri Lanka & 47.4 & 66.9 & 83.1 & 103.1 & 128.0 \\
\hline South Asia & 1589.8 & 2246.4 & 2788.3 & 3461.0 & 4295.8 \\
\hline Scenario 2 & \multicolumn{5}{|c|}{ 4\% agricultural growth (to attain household food security and alleviation of poverty and hunger) } \\
\hline Bangladesh & 101.2 & 162.1 & 217.6 & 292.3 & 392.3 \\
\hline India & 1258.3 & 2015.6 & 2705.8 & 3632.6 & 4876.5 \\
\hline Nepal & 24.1 & 38.7 & 52.0 & 69.7 & 93.6 \\
\hline Pakistan & 158.8 & 254.3 & 341.5 & 458.4 & 615.5 \\
\hline Sri Lanka & 47.4 & 75.9 & 101.9 & 136.7 & 183.5 \\
\hline South Asia & 1589.8 & 2546.7 & 3418.8 & 4589.7 & 6161.4 \\
\hline
\end{tabular}

*Source. Singh, 2009, APAARI

\section{Investment on basic infrastructure development}

Agriculture is a complex phenomenon and its development rests on infrastructure development by supporting allied sectors. To enhance products of comparative advantage such as crops, horticulture commodities (fruits, vegetables and vegetable seeds), non-timber forest product (NTFP) such as Yarcha gumba, Kutki, Panchaunle, saffron, mushroom, tea, coffee, large cardamom, medicinal herbs, handy craft product and many more, and livestock product (meat, milk and milk product, carpet and Pasmina wool production) there needs construction of storage facilities, ware house, cold storages, and market development in potential niches along with technology development for these commodities. Aside from this, a good network of link road connecting north-south corridor for linking hills and mountains with Terai and valley floor are necessary prerequisite of basic infrastructure development. To exploit agriculture for reducing poverty there is a need to support other allied sectors. Fan et al, (1999) had shown a unique case of India how number of poor has been decreased per million investments on different sectors that have synergic effect on agriculture (Table 4). This suggests that there is the evidence of investment on these areas which can yield relatively high rates of economic return and also significantly lessen poverty and environmental and resource degradation.

Table 4. Incremental effects of government spending on poverty, India

\begin{tabular}{lcc}
\hline Investment sector & $\begin{array}{l}\text { Decrease in number of poor, per } \\
\text { million Rupees spent }\end{array}$ & Rank \\
\hline Research and Development & 91.4 & 2 \\
Irrigation & 7.4 & 5 \\
Roads & 165 & 1 \\
Education & 31.7 & 3 \\
Power & 2.9 & 8 \\
Soil and Water & 6.7 & 6 \\
Rural Development & 27.8 & 4 \\
Health & 4 & 7 \\
\hline
\end{tabular}

Source. Fan et al; 1999 


\section{Adoption and mitigation strategy of climate change}

It has been experienced that effect of climate change in general and agriculture in particular has been observed (Paudel, 2012) and widely accepted in Nepal. This can be addressed by applying mitigation and adoption strategies. Of the several options Nepal can select adaptation and options based on hazard specificity and location specific preferences. FAO (2009) has provided practices to cope up with climate change hazards as below.

\section{Rain water harvesting and soil moisture conservation}

More than $80 \%$ of the total annual rainfall in Nepal is received during the rainy season (June September). On average, $65 \%$ of the total cultivated land is rainfed and yields are low. Further, livestock rearing as a livelihood activity in mid-hills and Terai requires adequate water both for cultivating fodder crops (and/or pastures) and for drinking. Water harvesting becomes essential to support livelihood activities throughout the year.

\section{Improvement of degraded land}

More than $90 \%$ of the population in Nepal is dependent upon the land for their fulfillment of sic needs (food, fuel, fibre and timber). Land degradation is declining in land quality or reduction in its potential productivity. Natural hazards like landslides in the hills, drought in the most of the areas of the country and flooding in the foothills and the Terai have frequently contribute to land degradation leading to poor socio-economic conditions and deterioration of natural ecosystems. Improvement of degraded land contributes to climate change adaptation and mitigation together with potential benefits for disaster risk reduction.

\section{Slope stabilization and management}

Nepal is a mountainous country; approximately $86 \%$ of the area is characterized by steep hills and mountains. One of the major causes of slope instability produced by human activities is deforestation in the hills and mountains. Slope Agriculture Land Technology (SALT) is one of the practices identified for promotion. Slope land management by plantation of fodder trees and appropriate crops such citrus, tea, coffee in terrace to control erosion should be promoted in midhills. Another option prioritized to stabilize the slopes is the hedge row planting. The intervention would identify best suitable model for the mid-hill region.

\section{Management of high/low temperature stress}

Temperature records of the last 30 years indicate increasing trend and the warming seems to be consistent and continuous after the mid-1970s. The average warming in annual temperature between 1977 and 1994 was $0.06^{\circ} \mathrm{C} /$ year and warming is more pronounced in high and mid hill regions of Nepal and lower in the Terai regions. Viable practices should be identified for field demonstration with farmers to reduce the impact of temperature fluctuations such as tunnel/plastic house farming and off season vegetable cultivation and community centered small scale fruit (apple, apricot, walnut, mandarin) and vegetable, potato seed storage. Tunnel farming technology is suitable and preferred by the small-farmers to produce off-season vegetables. Hence priority should be given for 
the development of localized tunnel farming technology by using new ways and techniques which are being practiced in road accessible areas of central and western mid hills along the KathmanduPokhara and Pokhara-Butwal, Pokhara-Baglung high ways.

\section{Crop diversification}

Nepal is broadly divided from east to west into three agro-ecological zones of approximately equal area. From the climatic point of view, in the plains or Terai there is hot and humid or subtropical to tropical climate, while in the hills both subtropical climate in the foothills and temperate climate on the top of the hills prevail. The Southwest zone is the Terai or plains, which are the northern extension of the Gangetic Plains of alluvial soils and have an elevation of 100-300 meters above mean sea level (msl). The middle zone comprises the less densely populated hills, which are cut by a series of valleys. Attitude ranges from 250-4,000 msl, and the zone is characterized by steep valleys that are often terraced for extensive agriculture. The topography of the hill zone results in different microclimates that can be suited to specific crops. To the north is the mountain zone which extends to over 8,000 msl. Based on the prevailing climatic conditions, different types of crops can be grown. Primarily, rice, wheat, legumes and oilseeds are the major commodities of the Terai, rice, maize, wheat, pulses and oilseed are major commodities in the hills and potato, barley, buckwheat and amaranthus, and different millets are the commodities suitable for the mountains. Based on the above conditions the suitable cropping patterns are being promoted. However, there is local scale dry and wet spells which affect these crops and needs intercropping systems to stabilize the productivity. Farmers in mid-hills prefer to grow soybeans/beans and zinger with maize as an intercrop to reduce the risk of drought.

\section{Community based seed production and user groups}

Seed is the important inputs for meeting food security and increase productivity. There is less than $5 \%$ formal seed replacement of improved varieties of important food crops and around $95 \%$ of seed replacement comes from farmers to farmers or informal sources of seeds produced locally. Quality seed alone can increase up to 10-25\% productivity of crops. Therefore research has shown that seed production groups for important food crops (rice, maize, wheat, barley, millet) have resulted encouraging results in many parts of the country. Improved seed produced by users groups in community based concept has helped increased crop production. The problem of seed produced in the community need market linkage through effective extension systems. Source seed for communities should be provided by research institutions and resource centers.

This engages community members to use the locally available resources to reduce the impact of natural hazards and extreme climate events.

\section{Resource conservation}

Practice of cultivating rice and wheat is unique in Indo-Gangetic Plains because of suitable thermal conditions for both crops during the annual cycle in warm-temperate and sub-tropical areas. Since the 1960s, there has been substantial increase in the area cultivated to rice - wheat in Terai regions. Rice and wheat yields in warm environments can be raised significantly by modifying agronomic practices. Conservation agriculture involves significant reductions in tillage, surface 
retention of adequate crop residues, and diversified, economically viable crop rotations. Along with other resource-conserving farming practices, conservation agriculture can improve rural incomes and livelihoods by reducing production costs, managing agro-ecosystem productivity and diversity more sustainably, and minimizing unfavorable environmental impacts, especially in small and medium-scale farms. Conservation agriculture with minimum tillage, zero tillage, surface seeding of wheat in the rice - wheat system, bed planting and arobic rice and System of Rice Intensification are the better mix showing climate change adaptation and mitigation synergies.

\section{Drought tolerant varieties of crops}

Clearly, rice, wheat and maize yields in lower latitudes may decrease due to global warming, which may be further affected by water scarcity or drought. One approach to dealing with these heatrelated constraints is to improve rice, wheat and maize germplasm to provide higher tolerance to stresses associated with these environments. Hence, the new varieties screened by NARC should be demonstrated to the farmers focusing on enhancing the crop yield potential and to maintain yield under higher temperatures. In this way, they will assist in building cropping system resilience to the global warming and natural hazards that could jeopardize the livelihoods of resource-poor farmers who depend on the rice, wheat and maize harvest.

\section{Reference}

Bhattarai, AN. 1990. As cited by Paudel et al. (2006) In A retrospective and perspective of outreach research in Nepal. Agricultural Development Journal 3. 1-19. DoA, MoAC, Nepal.

Dahal, H and DR, Khanal. 2010. Food security and climate change adaptation framework. Issues and challenges.2010. http.//www.moac.gov.np/publications downloaded on 28 June 2010.

Fan, S; PBR Hazell; and S, Thorat. 1999. Linkages between Government Spending, Growth and Poverty in Rural India. Research Report No. 110. International Food Policy Research Institute. Washington, DC as cited by RB, Singh.2009 in Regional Report on Agricultural Research for Development in the Asia-Pacific Region. APAARI and ADB.

FAO (Food and Agriculture Organization).2009. www.fao.org/. Downloaded on 4 July 2010. Gauchan, D and S Yokoyama. 1999. Farming systems research in Nepal. Current status and future agenda. National Research Institute of Agricultural Economics, Ministry of Agriculture, Forestry and Fishery (MAFF) Tokyo, Japan. Research Report No.24.

Gurung, BS. 1994. Research outreach program in the western hills. An experience of extension partner. Proceedings of the Second National Outreach Research Program, 29-31 March 1994, Lumle, NARC.

MoAC (Ministry of Agriculture and Cooperative). 2009. Selected Indicators of Nepalese agriculture and Population. Statistical Information on Nepalese Agriculture, Agribusiness Promotion and Statistical Division, Kathmandu, Nepal. 
MoAD (Ministry of Agriculture Development). 2012. Selected Indicators of Nepalese agriculture and Population. Statistical Information on Nepalese Agriculture, Agribusiness Promotion and Statistical Division, Kathmandu, Nepal.

NARSC (Nepal Agricultural Research Service Centre).1987. Policy guidelines. Research outreach policy and guidelines, Katmandu, Nepal.

ORD (Outreach Research Division).2000. Proceedings of Fifth National Outreach Research Workshop, 30-31 May 2000,ORD, Khumaltar, NARC.

ORD (Outreach Research Division).2007.A synoptic history of agriculture development and outreach research in Nepal. 2007. Proceedings of the $8^{\text {th }}$ National Outreach Research Workshop, 19-20 June, 2007. MN Paudel, B Mishra, NS Thakur, PP Khatiwada, SP Neopane, SM Shrestha (eds.) NARC, kathmandu, Nepal. Pp 429.

Paudel, MN.2012. Adaptation mechanisms in agriculture for climate Change in Nepal. Hydro Nepal, Special Issue, Journal of water, energy and environment. pp 81-85.

Paudel, MN and NS Thakur.2008. Acheivement of outreach research for agro-technology generation and transfer. An experience of Nepal. SAARC Journal of Agriculture 6.1-10. SAARC Agriculture Centre, Dhaka, Bangladesh.

Paudel, MN, NS Thakur, D Gauchn and RP Upreti. 2006. A retrospective and perspective of outreach research in Nepal. Ag Dev J 3. 1-18. DoA, MoAC, Nepal.

RB, Singh. 2009. Regional Report on Agricultural Research for Development in the Asia-Pacific Region. Asia-Pacific Association of Agricultural Research Institutions (APAARI) and Asian Development Bank (ADB) In Collaboration with. Global Forum on Agricultural Research (GFAR)

THT( The Himalaya Times) English daily News paper issues articles on food security and poverty related publications in different dates up to February 25, 2009, published by international media network (Pvt.) Kathmandu, Nepal.

TKP (The Kathmandu Post), English daily Newspaper issues articles on food security and poverty related publications in different dates up to February 25, 2009, published and printed by Kantipur publication Pvt. Ltd. Kathmandu, Nepal.

Ujyalo FM 90 MH. 27 June 2009. Kathmandu, Nepal.

Republica, English daily Newspaper.2010. May 30, 2010 Published and printed by Nepal Republica Media (P) Ltd, Kathmandu, Nepal.

Campaign ambassador speaks - Apa Sherpa. 2010. Retrieved on May 10, 2010.

http.//climate4life.org/the-campaign/campaign-ambassadors/apa-sherpa.html. 